\title{
Influence of Market Information on Decision to Invest through Nairobi Securities Exchange among Youth Groups of Kisumu County in Kenya
}

\author{
John Kibegwa ${ }^{1}$, Barbara Namiinda ${ }^{2}$, Susan Nzioki $^{3}$ \\ ${ }^{I}$ Student of Master of Science in Finance and Investment of Kenya Methodist University \\ ${ }^{2}$ Lecturer, Department of Business Administration, Kenya Methodist University \\ ${ }^{3}$ Lecturer, Department of Business Administration, Kenya Methodist University
}

\begin{abstract}
The challenges associated with youth employment and participation in economic development has been a key concern world over, especially in developing economies. The youths in Kenya are specifically looked at because of the pivotal role that they play in the Kenyan economy and the emphasis the government has put on youth empowerment programs to enable them to improve their financial welfare and participate in economic development as a way of achieving the tenets of Vision 2030. The government through the youth enterprise fund has invested heavily in providing seed capital for youth willing to start their own businesses. The Nairobi securities exchange provides lucrative investment opportunities following the revolutionalization that has taken place in the market. However, the number of youth investing through it is still low. The CMA has also made significant efforts in enhancing access to market information by creating online platforms as well as the use of mobile phones and training programs for youth in universities and tertiary institutions. However there is a high population of youth staying in rural and urban areas organized into youth groups supported by government with seed capital programs such as the youth enterprise fund who may not have been reached out by these programs. This study therefore sought to analyze the investment patterns and the influence of market information on the youth's decisions to invest through the NSE focusing on youth groups in Kisumu County. The study targeted the chairpersons of the youth groups or their representatives who were knowledgeable on the group investment strategies. The target population therefore was 380 chairpersons of youth groups from which a sample of 79 chairpersons was selected using stratified and random sampling method. Secondary data was obtained from the Youth Enterprise Fund, Nyanza Region for the four constituencies in Kisumu County while primary data was collected using questionnaires administered to the chair persons. The data collected was analyzed using descriptive statistics which included: mean, mode, frequencies and percentages while the relationships between market factors were determined using the t-statistics for two independence samples. The study revealed that market information had statistically significantly influence youth's decisions to invest through the Nairobi Securities Exchange. The study therefore recommended that the Capital Markets Authority in Kenya should link the youth to platforms for accessing real-time capital markets data as well as empower them on how to use the data in making investment decisions.
\end{abstract}

\section{Introduction}

Many countries are supporting youth ministries, youth policies and youth programs, and there seems to be greater appreciation that young people are the future of their development (Yunus, 2008). Like the rest of the world, the Kenya government has embraced entrepreneur development through formation of policies favorable to development of small enterprises among the youths as a way of meeting its development goals as envisaged in the Vision 2030. Youth Enterprise Development Fund (YEDF) was founded in June 2006 by the government of Kenya as a strategic move towards arresting unemployment which is virtually a youth problem. The fund targets all forms of youth owned enterprises whether owned individually, as accompany, in groups, in cooperatives or any legal forms of business ownership (GOK, 2008).The fund has partnered with 36 financial intermediaries which include; Non-Governmental Organizations, Micro-Finance Institutions, Savings and Credit Cooperatives from which the youths either individually or as an organized entities access funds to start and expand their businesses. Through this initiative the youth can access loan up to Kenya shillings one million at the interest rate of $8 \%$ per annum. For loans above Kshs.1million, the financial intermediary must seek authority from the fund. (YEDF Report, 2011).The Nairobi Securities Exchange (NSE) acknowledge the fact that the youth constitute the majority of population in the world where in Kenya the age group 15 to 34 years represent approximately $35.39 \%$ of the population. This proportion of youth is expected to form the bulk of the population in the next 10-20 years. Therefore it is likely to have a significant impact on investment in NSE in the future. As a result, inculcating a saving and investment culture amongst the youth is synonymous to safeguarding the future of the country's investment markets. In cognition of these facts, and the challenges encountered by the 
youth, the NSE in collaboration with Smart Youth Investment Limited launched the NSE Investment Challenge in the year 2008. The financial literacy program sponsored by NIC Securities and CPF Financial Services.

The program target to empower youths attending universities and other tertiary institutions countrywide with knowledge of investing and savings through an online simulation of trading. The main goals of the investment challenge initiative is to connect to the youth market educationally and build their character of saving and investing, enhance financial management and entrepreneurial skills amongst the youths, encourage a culture of thrift or saving amongst the youth. Further, the program aim at teaching the risks and gains involved while trading in stocks and bonds, assisting in investing savings in productive enterprises and to demystify trading of Stocks \& Treasury Bonds at the Nairobi Securities Exchange amongst the youth. By the end of 2015, the program had reached and trained 60,000 youths across the country from over 240 institutions (NSE, 2015). This implies that a lot of education and knowledge transfer has been done among youth from all corners of the country including Kisumu County.

Following the efforts to bring youths on board in the NSE, the Capital Markets Authority by March 2015 realized an increase in the number of youths seeking investment opportunities at the Nairobi Securities Exchange compared to previous years (CMA, 2015). The increase was attributed to level of information dissemination and lower prices of shares, giving the youth with little income more opportunities to invest. The trends also indicated that as the stock prices comes down, the level of youth investments at the NSE was on the increase. Customer preferences also play a major role in identification of stocks to invest in among the investors through the herding effect. The youths tend to purchase shares which are most traded to avoid investing in stock with low returns. However in the retail investments, which comprise the small end investors rather than institutional investors, the numbers were still relatively small with only 11 to 13 percent investing (Capital Markets Authority, 2015). This implied that although the number of youth and local individual investors in the NSE were growing, overall the proportion was low and there was room for more local investors.

Kisumu County has seven constituencies which are situated both in rural and urban areas with an estimated population of 1,300,000 (Census, 2006). High poverty levels is one of the major development challenge in Kisumu County. Estimates show that over $60 \%$ of the population live under poverty line compared with national average of $46 \%$ as at 2006.Poverty levels are higher in urban areas (70\%) compared to rural areas $(63 \%)$. As a measure of reducing the poverty levels in this county a number of youths have formed groups as collective effort towards reducing the poverty levels through mobilizing resources to start businesses and economic projects. As at 2015, this devolved unit had 14,500 youth groups registered under the ministry of Culture and Social Services (Kisumu CIDP, 2013).Out of these groups in the county, 380 groups are also registered with the YEDF and have obtained funds for their various economic projects. The common business activities for these groups include; fishing, farming, real estates, operating shops, money lending and investment in securities exchange.

\section{Problem Statement}

The government of Kenya and other stakeholders in the Capital market have made substantial efforts to encourage, finance and support the youths in trading of shares at the Nairobi securities exchange market. This has been part of the government strategies for creating youth employment, eradicating poverty, growing the economy and achieving the tenets of Vision 2030. Youth Enterprise Development Fund provides youths in Kenya with seed capital to start business either individually, in groups or in any legally recognized entity. The Capital Market Authority too has partnered with other institutions to come up with youth investment programs such as the Smart Youth Investment (SYI) program which targets the youths in Universities and tertiary colleges to equip them with knowledge of saving and investment in stocks. Through these programs, Kenyan government and the capital Market Authority aims at eliminating fears of trading in shares at the NSE, creating investment attitude and infrastructure and removing the bottlenecks associated with stock trade for the youths to participate effectively in the stock market. The CMA has also made significant efforts in enhancing access to market information by creating online platforms as well as the use of mobile phones and training programs for youth in universities and tertiary institutions. However, there is a high population of youth staying in rural and urban areas organized in to youth groups supported by government with seed capital programs such as the youth enterprise fund who may not have been reached out by these programs. Their investment strategies, behavior and the influence of market information and need to have not been well determined. This study therefore sought to analyze the investment patterns and the influence of market information on the youth's decisions to invest through the NSE focusing on youth groups in Kisumu County, Kenya.

\section{Objective}

To examine the influence of market information on investment decisions among youth groups in Kisumu County. 


\section{Research Hypothesis}

Market information does not have a significant influence investment decisions among youth groups in Kisumu County

\section{Literature Review}

On their study of five factors; firm image, accounting information, advocate recommendation, neutral information and personal financial on their effect on investment decisions, Gnani, Ganesh and Santhi, (2012) found out that all the five factors affect the investors decisions, however, they have varying degree of intensity. Few have more while others have lesser effect. Accounting information has the highest intensity towards affecting the investor's behavior and advocate recommendation has the least effect on the investors' decision making.

In Bangladesh, Rashid and Nishat, (2009) identified the most influencing factors of investor decisions as efficiency of the company, inflation rate, easy and quick transactions, transaction cost, access to the company and industry information, quality of information and prior knowledge of securities.Al-Tamimi, (2005) investigated the factors influencing individual investor behavior on the United Arab Emirates (UAE) financial markets. The study found the six most influencing factors in order of importance were: expected corporate earnings, get rich quick, stock marketability, past performance of the firm's stock, government holdings and the creation of the organized financial markets, family member opinions and gut feeling on the economy.

Nagy and Obenberger, (1994) examined the factors influencing investment behavior and found out that classical wealth maximization criteria are the most important to investors, even though investors employ diverse criteria when choosing stocks. Sultana and Pardhasadhi, (2012) investigated factors influencing Indian individual equity investors' decision making and behavior. After applying factor analysis, the 40 attributes were reduced to ten factors of individual eccentric, wealth maximization, risk minimization, brand perception, social responsibility, financial expectation and advocate recommendation factors.

\section{Research Design}

\section{Methodology}

This study employed descriptive survey research design. This design was suitable for this kind of study because the researcher intended to collect data to ascertain facts relating to youth investment decisions in NSE. This kind of research methodology makes use of surveys to solicit investors informed opinion.

\section{Target Population}

This study targeted group officials of youth groups registered and funded by Youth Enterprise Development Fund in Kisumu County since its inception in the year 2006 to 2015. The youth group chair persons are charged with the day to day management of group activities and are involved in all group investment decision making. Therefore, they have knowledge on their group investments and investment decisions. Kisumu County is considered vital for this research because its constituencies are both in urban and rural areas hence this will guide the researcher to make unbiased conclusions of the youth groups investment behavior patterns. There were 380 groups with an average of eight members each that have been funded by YEDF through Constituency Youth Enterprise Scheme (C-YES). The target population comprised of 380 youth group chair persons. In the absence of the chair person, any other person in charge or in acting capacity at that particular time who was able to give full information on the youth group investments represented the group.

\section{Sample Size and Sampling Procedure}

To obtain the desired sample size for the study, Nassiuma, (2002) formula was used as shown below:

$$
\begin{aligned}
& n=\frac{N c v^{2}}{c v^{2}+(N-1) e^{2}} \\
& \text { Where: } \\
& \mathrm{n}=\text { Sample size } \\
& \mathrm{N}=\text { Population } \\
& \left.\mathrm{C}_{\mathrm{v}}=\text { Coefficient of variation (take } 0.5\right) \\
& \mathrm{e}=\text { Tolerance at desired level of confidence, take } 0.05 \text { at } 95 \% \text { confidence level }
\end{aligned}
$$

Therefore:

$$
n=\frac{380 * 0.5^{2}}{0.5^{2}+(380-1) 0.05^{2}}=79
$$

Therefore the sample size comprised of 79 youth group chairpersons in Kisumu County, Kenya. This sample was selected using the stratified random sampling technique where it was distributed proportionately in each constituency based on the number of youth groups registered. 
Table 1: Population and Sample Distribution

\begin{tabular}{lcc}
\hline Staff Category & Chair Persons & \multicolumn{2}{c}{ Sample size } \\
& & $N_{i}=\left(\frac{N}{N}\right) n$ \\
\hline Kisumu West & & 28 \\
Kisumu East & 135 & 32 \\
Kisumu Central & 153 & 12 \\
Seme & 60 & 7 \\
Totals & 32 & $\mathbf{7 9}$ \\
\hline
\end{tabular}

The researcher used stratified random sampling technique to obtain the required youth group chairpersons in each constituency. Stratified sampling was used because the youth groups in each constituency could have had different investment characteristics thus each constituency had an equal chance of being represented in the sample. Random sampling was applied to obtain individual respondents in each constituency. The use of random sampling was meant to ensure that each chairperson in each youth group per constituency had an equal chance of being selected. Thus this eliminated selection biases.

\section{Data collection instruments}

This study used both primary and secondary data. Primary data was collected using structured and semi-structured questionnaires with closed-ended and open-ended questions. The rating of opinions was then done using a five point likert scale of $1-5$ where 1 represented strong disagreement while 5 represents strong agreement with the statements being assessed. The questionnaire enabled the researcher to reach a wide number of respondents within a short time period. The questions aimed at addressing the research objectives. The questionnaires were self-administered by the researcher. Secondary data will be obtained from Youth Enterprise Development Fund-Nyanza Region and Nairobi securities exchange. To improve on reliability in this study, piloting of the questionnaires was done on chairpersons of 8 groups from Kisumu West Constituency. However, those who took part in the pilot study were not part of the sample selected for the actual study. Items in the piloting questionnaires were analyzed using Cronbach's reliability coefficient in the statistical package for social scientists (SPSS, 19.0). The study tool achieved an overall reliability coefficient of 0.719 thus the study was adopted and administered to the respondents.

\section{Data Analysis}

Thedata was then analyzed with the help of the Statistical Package for Social Sciences (SPSS) for windows version 21.0. SPSS is commonly used in the Social Sciences because it is capable of handling large amounts of data and can perform all of the analysis covered in the text and much more. Descriptive statistics were computed to analyze and summarize the data including mean, mode, median, frequencies and percentages. To determine the influence of market information on youth's decisions to invest through the NSE, youths were categorized into two groups: those who invested through the NSE and those who never invested through the NSE. These constituted two independent samples. Equality of means for each market factor was then computed using the t-test analysis. The judgment on the statistical significance of the mean differences was then done based on a significance level of 0.05 .

\section{Response Rate}

\section{Findings}

The sample size of the study comprised of 79 leaders of youth groups in Kisumu County out of which 69 responded to the questionnaires. Therefore the study achieved a response rate of $87.3 \%$. This according to the researcher was a high response rate due to the personal efforts to administer the questionnaires.

\section{Duration of Existence of Group}

The duration in which the youth groups had been in existence were also determined and found out that their group age varied between 2 and 9 years. However the mean duration was 4.75 years which translated to 4 years and 9 months. This scenario could be attributed to the governments' initiative of the year 2013 to uplift the youth through the Uwezo Fund programme which encouraged youth to form groups in order to be able to benefit from the fund.

\section{Group Membership}

The group membership was also determined by analyzing the number of members in the group in total as well as determining the number in particular gender as shown on Table 2. 
Table 2: Group Membership

\begin{tabular}{llllll}
\hline & N & Min & Max & Mean & Std. Deviation \\
\hline Number of members & 69 & 9.00 & 65.00 & 24.72 & 14.27 \\
Male Members & 69 & 2.00 & 42.00 & 14.97 & 10.04 \\
Female Members & 69 & 0.00 & 24.00 & 9.90 & 6.43 \\
\hline
\end{tabular}

The findings in Table 4.2 revealed that group membership varied where groups with the least number of members had 9 while those with the highest number had 65 members. On average, groups had 25 members. Aggregation by gender revealed that some groups had no female members at all while the group with least number of male members had 2. The average number of female members was 10 while that of male members was 15 . This shows that youth groups in Kisumu County had both male and female members although the male gender were more represented compared to female members.

\section{Value of Group Investment}

The value of group investments was also determined by asking group leaders to state their current total investments as a group.

Table 3: Value of Group Investment

\begin{tabular}{lccccc}
\hline & N & Min & Maxi & Mean & Std. Deviation \\
\hline Value of group investment & 69 & 73000.00 & 2433215.00 & 491791.26 & 595832.97
\end{tabular}

Analysis of the groups' investments in Table 4.3 shows that the group that cited least investment had a total investment of Ksh. 73,000-2,433,215. This shows that

\section{Youth Investment Strategy}

The investment strategies of youth groups were also explored based on the groups understanding and mode of investment in four categories: investment in fixed assets, financial assets, businesses and mixed models as shown in Table 4.

Table 4: Investment Strategy

\begin{tabular}{lcc}
\hline & Frequency & Percent \\
\hline Physical Assets & 17 & 24.6 \\
Financial Assets & 18 & 26.1 \\
Business & 25 & 36.2 \\
Mixed Models & 9 & 13.0 \\
Total & $\mathbf{6 9}$ & $\mathbf{1 0 0 . 0}$ \\
\hline
\end{tabular}

The study findings revealed that $36.2 \%$ of the youth groups adopted the business approach where they preferred to start and run their own businesses. $26.1 \%$ invested in financial assets while $24.6 \%$ invested in physical assets. However, $13.0 \%$ adopted a mixed model approach which involved a combination of these strategies.

\section{Investment through the NSE}

The study also sought to explore the investment patterns for those youth groups who invested in NSE as well as those who did not. First was to determine whether youth group members were aware of investment through the NSE. Out of the group leaders who participated in the current study, $75.36 \%$ were aware of investment through the NSE while $24.64 \%$ were not. This shows that investment through NSE was not a new phenomenon for youth since majority of the youth were aware of its existence. Other than being aware of the NSE investment platform the study further sought to determine the number of groups that participated in the buying and selling of stocks through the NSE. The findings revealed that $34.78 \%$ of the youth groups who participated in the study were involved in buying and selling of stocks while $65.22 \%$ did not. This shows that investment in NSE was part of the investment options embraced by the Youth Groups in Kisumu County.

Investment Patterns for Youth who invested through the NSE

For those youth groups who have been investing in the NSE, the study sought to understand their investment characteristics. These included: the period for which youth groups had been investing in the NSE, number of companies invested in and their previous annual rate of returns.

Table 5: Duration of Investment at NSE

\begin{tabular}{llcccc}
\hline & $\mathbf{N}$ & Min & Max & Mean & Std. Deviation \\
\hline $\begin{array}{l}\text { How Long have you invested in } \\
\text { NSE }\end{array}$ & 24 & 2.00 & 4.00 & 3.33 & 0.76 \\
How many Companies & 24 & 2.00 & 5.00 & 3.08 & 0.97
\end{tabular}


Regarding the duration of investment at the NSE, some groups indicated to have invested through NSE for up to 4 years while the least had been in NSE for 2 years. The average duration for which groups invested in NSE was 3.33 years ( 3 Years and 4 months). In terms of the number of companies invested in, some groups indicated to have bought stocks of as high as5 different companies while the least had invested in stocks of 2 companies. On average, youth groups invested in stocks of three companies. This shows that youth of Kisumu County who invested in NSE were keen on distributing their investment through diversification of their portfolios. The annual rate of return from the portfolios varied where the lowest recorded annual rate of return for the entire portfolio was $17.0 \%$ while the highest recorded annual rate of return was $60.0 \%$. The average return recorded was $31.50 \%$.

\section{Types of Stocks Invested}

The types of stocks that youth groups were interested in were also determined as shown on Table 6. This was a multiple response question which allowed respondents to select more than one stock category that their groups invested in.

Table 6Types of Stocks Invested

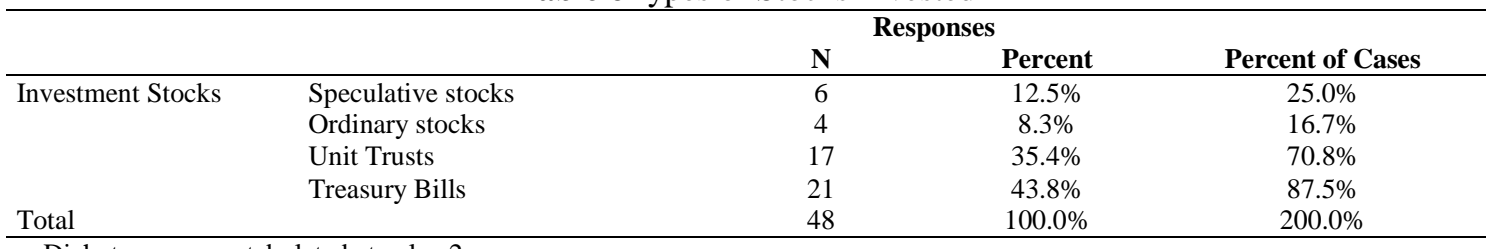

a. Dichotomy group tabulated at value 2 .

The findings on Table 4.6 shows that treasury bills were the most preferred type of investment since it was adopted by $87.5 \%$ of the youth groups who invested through the NSE. Unit trusts were the second most preferred by $70.8 \%$ followed by speculative stocks adopted by $25.0 \%$. Ordinary stocks were the least preferred by $16.7 \%$ of the youth groups. All the groups invested through investment managers.

\section{Reasons for Youth Not Investing through the NSE}

The study sought to know from the leaders of youth groups who did not invest in the NSE the reasons prompting them not to invest. Various reasons were cited by youth group leaders such as: lack of sufficient capital, lack of access to the markets, limited knowledge on how the investment markets work and the complexity of the trading through the NSE. The study further sought responses from the youth groups who were not investing at the NSE on a list of parameters to determine the extent to which they influenced their decisions to invests at the NSE or not.

Table 7:FactorsAffecting Youth Investment in NSE

\begin{tabular}{|c|c|c|c|c|c|c|c|}
\hline Factor & Very High & High & Moderate & Low & Very Low & Mean & SD \\
\hline Dividend previously paid & $\begin{array}{c}17 \\
(37.8)\end{array}$ & $\begin{array}{c}9 \\
(20.0)\end{array}$ & $\begin{array}{c}10 \\
(22.2)\end{array}$ & $\begin{array}{c}1 \\
(2.2)\end{array}$ & $\begin{array}{c}8 \\
(17.8)\end{array}$ & 3.58 & 1.47 \\
\hline Expected dividends & $\begin{array}{c}6 \\
(13.3)\end{array}$ & $\begin{array}{c}24 \\
(53.3)\end{array}$ & $\begin{array}{c}14 \\
(31.1)\end{array}$ & $\begin{array}{c}1 \\
(2.2)\end{array}$ & $\begin{array}{c}0 \\
(0.0)\end{array}$ & 3.78 & 0.70 \\
\hline Stock marketability & $\begin{array}{c}6 \\
(13.3)\end{array}$ & $\begin{array}{c}13 \\
(28.9)\end{array}$ & $\begin{array}{c}16 \\
(35.6)\end{array}$ & $\begin{array}{c}5 \\
(11.1)\end{array}$ & $\begin{array}{c}5 \\
(11.1)\end{array}$ & 3.22 & 1.17 \\
\hline Recent price movement & $\begin{array}{c}7 \\
(15.6)\end{array}$ & $\begin{array}{c}23 \\
(51.1)\end{array}$ & $\begin{array}{c}15 \\
(33.3)\end{array}$ & $\begin{array}{c}0 \\
(0.0)\end{array}$ & $\begin{array}{c}0 \\
(0.0)\end{array}$ & 3.82 & 0.68 \\
\hline Affordability of shares & $\begin{array}{c}1 \\
(2.2)\end{array}$ & $\begin{array}{c}10 \\
(22.2)\end{array}$ & $\begin{array}{c}14 \\
(31.1)\end{array}$ & $\begin{array}{c}12 \\
(26.7)\end{array}$ & $\begin{array}{c}8 \\
(17.8)\end{array}$ & 2.64 & 1.09 \\
\hline Capital appreciation & $\begin{array}{c}11 \\
(24.4)\end{array}$ & $\begin{array}{c}25 \\
(55.6)\end{array}$ & $\begin{array}{c}9 \\
(20.0)\end{array}$ & $\begin{array}{c}0 \\
(0.0)\end{array}$ & $\begin{array}{c}0 \\
(0.0)\end{array}$ & 4.04 & 0.67 \\
\hline $\begin{array}{l}\text { Attractiveness of non-stock } \\
\text { investments }\end{array}$ & $\begin{array}{c}15 \\
(33.3)\end{array}$ & $\begin{array}{c}20 \\
(44.4)\end{array}$ & $\begin{array}{c}10 \\
(22.2)\end{array}$ & $\begin{array}{c}0 \\
(0.0)\end{array}$ & $\begin{array}{c}0 \\
(0.0)\end{array}$ & 4.11 & 0.75 \\
\hline Expected losses in other investment & $\begin{array}{c}6 \\
(13.3)\end{array}$ & $\begin{array}{c}16 \\
(35.6)\end{array}$ & $\begin{array}{c}21 \\
(46.7)\end{array}$ & $\begin{array}{c}2 \\
(4.4)\end{array}$ & $\begin{array}{c}0 \\
(0.0)\end{array}$ & 3.58 & 0.78 \\
\hline Current economic indicators & $\begin{array}{c}18 \\
(40.0)\end{array}$ & $\begin{array}{c}14 \\
(31.1)\end{array}$ & $\begin{array}{c}13 \\
(28.9)\end{array}$ & $\begin{array}{c}0 \\
(0.0)\end{array}$ & $\begin{array}{c}0 \\
(0.0)\end{array}$ & 4.11 & 0.83 \\
\hline Fluctuations in market indices & $\begin{array}{c}7 \\
\text { (15.6) }\end{array}$ & $\begin{array}{c}11 \\
(24.4)\end{array}$ & $\begin{array}{c}24 \\
(53.3)\end{array}$ & $\begin{array}{c}3 \\
(6.7)\end{array}$ & $\begin{array}{c}0 \\
(0.0)\end{array}$ & 3.49 & 0.84 \\
\hline Inherent risks of stock & $\begin{array}{c}0 \\
(0.0)\end{array}$ & $\begin{array}{c}14 \\
(31.1)\end{array}$ & $\begin{array}{c}22 \\
(48.9)\end{array}$ & $\begin{array}{c}9 \\
(20.0)\end{array}$ & $\begin{array}{c}0 \\
(0.0)\end{array}$ & 3.11 & 0.71 \\
\hline
\end{tabular}


The first parameter was the dividends previously earned where $37.8 \%$ of the youth group leaders cited that it contributed very highly while $20.0 \%$ felt that it contributed highly and $22.2 \%$ moderately towards shaping their decisions not to invest at the NSE. The expected rate of return was cited to have very high influence by $13.3 \%$, high influence by $53.3 \%$ while $31.1 \%$ cited moderate influence. According to the youth group leaders, stock marketability contributed very high according to $13.3 \%$, highly according $28.9 \%$ and Moderate $35.6 \%$ to the group's investment decisions of to invest through the NSE among those groups who avoided NSE. Price movements too were critical in determining the youth investments decisions; $15.6 \%$ indicated that this had very high level of contribution while $51.1 \%$ cited high contribution and $33.3 \%$ moderate contribution. This implies that price movements were also key factors in making the youth to shy away from investment at the NSE.

The study also explored how affordability of shares influenced youth investment at the NSE and found out that only $2.2 \%$ cited that affordability of shares had very high impact on investment decisions while $22.2 \%$ felt that the contribution was high and $31.1 \%$ moderate. The rate at which capital appreciation influenced youth investment decisions was very high according to $24.4 \%$, of the youth group leaders, high according to $55.6 \%$ and moderate according to $55.6 \%$. The level of expected losses in was ranked very high by $13.3 \%$, high by $35.6 \%$ and moderate by $46.7 \%$ in influencing youth investment decisions among those youth groups who had not invested through the NSE.

The prevailing economic indicators also influenced youth investment decisions to a very high extent $(40.0 \%)$, while $31.1 \%$ rated the influence high and $28.9 \%$ moderate. Fluctuations in market indices was rated very high by $15.6 \%$, high $(24.4 \%$ )and moderate by $53.3 \%$ in influencing youths investment at the NSE particularly in discouraging the investment. The risks inherent in investing in stocks stock contributed moderately $(48.9 \%)$ in shaping investment decision; $31.1 \%$ felt that risks highly influenced investment decisions while none felt that risks had very high impact on investment decisions. Finally, youth group leaders revealed that the rate of return of individual stocks had very high (42.2\%), high $(53.3 \%)$, and moderate $(4.4 \%)$ influence in investment decisions for those youth who did not focus on the NSE.

The study further analyzed to compare the factors based on their level of influence in decision making and found out that: the rate of return of the stock stocks had the highest level of influence on investment decisions among youth groups in Kisumu County rated at a Mean $=4.38, \mathrm{SD}=0.58$ followed by the attractiveness of other investment vehicles (Mean $=4.11, \mathrm{SD}=0.75$ ), the prevailing economic indicators (Mean $=4.11, \mathrm{SD}=0.83$ ) and the expected level of capital appreciation capital appreciation (Mean $=4.04, \mathrm{SD}=0.67$ ).

\section{Market Information and Investment Decisions}

The main objective for the study was to examine the influence of market information on investment decisions among youth groups in Kisumu County. This was achieved by determining how youth reacted to the markets on the basis of information they had about the markets. These findings were presented in Table 8.

Table 8: Market Information and Investment Decisions

\begin{tabular}{|c|c|c|c|c|c|}
\hline & $\begin{array}{l}\text { Strongly } \\
\text { Agree }\end{array}$ & Agree & $\begin{array}{l}\text { Not } \\
\text { Decided }\end{array}$ & Disagree & $\begin{array}{l}\text { Strongly } \\
\text { Disagree }\end{array}$ \\
\hline $\begin{array}{l}\text { You prefer to buy local stocks than international stocks } \\
\text { because the information of local stocks is more } \\
\text { available }\end{array}$ & $\begin{array}{c}22 \\
(31.9)\end{array}$ & $\begin{array}{c}25 \\
(36.2)\end{array}$ & $\begin{array}{c}16 \\
(23.2)\end{array}$ & $\begin{array}{c}6 \\
(8.7)\end{array}$ & $(0.0)$ \\
\hline $\begin{array}{l}\text { You search the market for stocks that are poised to go } \\
\text { up because of an impending deal for a chance to make } \\
\text { money fast }\end{array}$ & $\begin{array}{c}28 \\
(40.6)\end{array}$ & $\begin{array}{c}30 \\
(43.5)\end{array}$ & $\begin{array}{c}11 \\
(15.9)\end{array}$ & $\begin{array}{l}0 \\
0.0)\end{array}$ & $(0.0)$ \\
\hline $\begin{array}{l}\text { You consider carefully the price changes of stocks that } \\
\text { you intend to invest in }\end{array}$ & $\begin{array}{c}23 \\
(33.3)\end{array}$ & $\begin{array}{c}38 \\
(55.1)\end{array}$ & $\begin{array}{c}8 \\
(11.6)\end{array}$ & $\begin{array}{ll}0 & \\
& (0.0)\end{array}$ & $(0.0)$ \\
\hline $\begin{array}{l}\text { Market information is important for your stock } \\
\text { investment }\end{array}$ & $\begin{array}{c}24 \\
(34.8)\end{array}$ & $\begin{array}{c}33 \\
(47.8)\end{array}$ & $\begin{array}{c}8 \\
(11.6)\end{array}$ & $\begin{array}{c}4 \\
(5.8)\end{array}$ & $(0.0)$ \\
\hline
\end{tabular}

Based on the investment market information available for youth in Kisumu County, 31.9\% strongly while $36.2 \%$ agreed that they preferred to buy local stocks than international stocks because the information of local stocks is more available. Although $23.2 \%$ were not decided, $8.7 \%$ disagreed. This shows the availability of market information especially on the local stocks was key in influencing youth investment decisions in Kisumu County. This agrees with Gnani, Ganesh and Santhi, (2012) who identified firm image, accounting information and advocate recommendation as key factors that on their effect on investment decisions. Majority of the youth 
$(84.1 \%)$ were in agreement that they searched the market for stocks that were poised to go up because of an impending deal for a chance to make money fast (40.6\% agreed while $43.5 \%$ strongly agreed). Only a small proportion indicated otherwise that they were undecided. This revealed youth information search practices were geared towards the stocks which had room for appreciation and growth. This was in line with the findings by Sultana and Pardhasadhi, (2012) on the Indian individual equity investors' decision making and behavior. They found out that key among decisions contributors was the wealth maximization.

Youth also indicated staying abreast with stock performances where $46.4 \%$ strongly agreed while $34.8 \%$ agreed. Very few were of a contrary opinion where $13.0 \%$ were not decided while $5.8 \%$ disagreed that they stayed abreast of stocks' performance on a daily basis as well as research to keep up with the daily financial trends. This shows that a larger proportion youth group leaders in Kisumu County were keen on the trends in the financial markets and kept daily updates. This was supported by Al-Tamimi, (2005) on the role played by information on stocks performance trends on investor decisions.

Further on the market information and investment decisions among youth in Kisumu County, the study revealed that majority of the youth group leaders considered carefully price changes for stocks that they were interested in investing in the future. This was according to $33.3 \%$ who strongly agreed and $55.1 \%$ who agreed. A small proportion of $11.6 \%$ however were not decided on this statement. This implies that majority of the youth were keen on searching information regarding what they perceived as future investments. This supports Al-Tamimi, (2005) study that identified past performance of the firm's stock as key market information that influence investors' decisions and moves.

There was also agreement among youth group leaders that market information was important for persons interested in stock investment. This was according to majority $82.6 \%$ of the youth group leaders where $34.8 \%$ strongly agreed while $47.81 \%$ agreed; a few $11.6 \%$ had no stand concerning this opinion while $5.8 \%$ strongly disagreed. This argument is well supported by (Gnani, Ganesh and Santhi, 2012; Rashid and Nishat, 2009). Concerning whether youth were able to anticipate the outcome of a given market and its performance, $33.3 \%$ were in agreement where $15.9 \%$ strongly agreed and $17.4 \%$ agreed that they were able to anticipate the end of good or poor market returns at the stock exchange market. On the contrary, $17.4 \%$ were not decided, $36.2 \%$ disagreed while $13.0 \%$ strongly disagreed. This shows that youth held mixed opinions on their ability to project the market performance using the current information. This could influence their decisions to invest through the NSE or not.

\section{Inferential Analysis}

The broad objective for the study was to assess the influence of market information on investment decisions at the Nairobi securities exchange amongst youth groups in Kisumu County. Thus the study sought rating from the youth on the factors under investigation. The study further sought to determine whether there were differences in scores on the market information between youth group leaders whose groups participated in the investment through the NSE and those who did not. This would provide information on whether the market information influenced youths' decisions to invest through the NSE or not. This was performed using the independent sample t-test analysis and the results were as shown on Tables $9 \& 10$

Table 9: Means on market information Groups Investment Patterns

\begin{tabular}{ccccc}
\hline & $\begin{array}{c}\text { Group engage in buying } \\
\text { of shares }\end{array}$ & N & Mean & Std. Deviation \\
\hline Market information & Yes & 24 & 4.1667 & .37403 \\
& No & 45 & 3.4861 & .43374 \\
\hline
\end{tabular}

The results on Table 4.12 shows higher scores in the mean rating on the market information by the youth group leaders who invested through the NSE compared to those who did not. Table 10 shows the statistical significance of the mean differences between the two groups. These results were further used to test

Table 10: T-test for Equality of Means for Market Factors

\begin{tabular}{cccccc} 
& $\mathbf{t}$ & df & $\begin{array}{c}\text { Sig. } \\
(\text { 2-tailed) }\end{array}$ & Mean Difference & Std. Error Difference \\
\hline Market information & 6.500 & 67 & .000 & .68056 & .10470 \\
\hline
\end{tabular}

\section{Hypothesis Testing}

The study hypothesis was:

Market information does not have a significant influence investment decisions among youth groups in Kisumu County. 
This hypothesis was tested by running independent sample t-test to determine the significance of the mean difference on the scores for market information between the youth groups who invested through the NSE against those did not. The T-test results on Table 10 shows that there was a statistically significant difference in the scores on market information between youth groups who invested through the NSE against those who did not $\left(\mathrm{t}_{67)}=2.100, \mathrm{p}<0.05\right)$. This implies that youth who had more information on the investment markets tended to invest more through the NSE compared to those who had less information. This therefore implies that access to accurate market information has significantly contributed in influencing youth to invest in the stock markets or not. The study therefore rejected the null hypothesis $\left(\mathrm{H}_{0}\right)$.

\section{Conclusion}

The findings of the study revealed that, the availability of market information especially on the local stocks was key in enabling youth to make investment decisions. Majority of the youth sought information on the stocks that were poised to go up because of an impending deal for a chance to make money fast. Besides, a larger proportion of youth were keen on the trends in the financial markets and kept track on daily basis. The youth also considered carefully price changes for stocks that they were interested in investing in the future. However there were mixed opinions on the youths' ability to project the future market performance using the current information. Further analysis revealed that youth who invested through the NSE scored significantly high on access and use of market information in investment decision making. This finding agrees with that of a study by Gnani, Ganesh and Santhi, (2012) which associated the investors decision on a given stock or company to be based on several informational features: firm image, accounting information, advocate recommendation, neutral information and personal financial. Besides Kadariya, (2012) established that youngsters took decisions considering the media coverage and friends recommendations as good source of information. The study therefore concluded that availability and use of market information played a significant role in influencing youth investment decisions at the NSE. Thus the amount of information available to the investor was critical in influencing their decisions. However, the youth manifested challenges in the use of current market information to predict the likely market scenario in the future. Therefore there is need for the CMA to link the youth to platforms for accessing real-time capital markets data as well as empowering them on how to use the data in making investment decisions.

\section{References}

[1] Al-Tamimi, H. (2005). Factors Influencing Individual Investor Behavior: An empirical study UAE Financial Markets. Athens: Aryan Hellas Limited.

[2] CMA (2015) More youths investing at the NSE. Nairobi: Capital Markets Authority

[3] Kadariya. S, (2012) Factors Affecting Investors Decision Making: A case of Nepalese capital market, Journal of research in economic and international Finance (JREIF), 1 (1), 16-30.

[4] Nagy, J and Obenberger, A. (2004).Factors Influencing Investor Behavior. Financial Analysts Journal, 50, 235 - 247.

[5] NSE (2015) Nairobi Securities Exchange Awards the Winners of the 2015 NSE Investment Challenge. Nairobi: Nairobi Securities Exchange

[6] Rashid, M. \&Nishat, M. (2009). Satisfaction of Retail Investor on the Structural Efficiency of the Market: Evidence from a Developing Country. Asian Academy of Management Journal, 14(2), 41-64

[7] Sultana, S.T., \&Pardhasaradhi, S. (2012). An Empirical Analysis of Factors Influencing Indian Individual Equity Investors' Decision making and Behavior. European Journal of Business Management, 4(18), 50-61

John Kibegwa. "Influence of Market Infrormation on Youth Groups Decisions to Invest Through the Nairobi Securities Exchange in Kenya." IOSR Journal of Business and Management (IOSR-JBM) 19.7 (2017): 68-76. 